\title{
A statistical analysis of value of imports in Nigeria
}

\author{
Nwaigwe, Chrysogonus Chinagorom; Iwu Hycinth Chukwudi \\ Department of Statistics, School of Science, Federal University of Technology Owerri, Imo State Nigeria
}

\section{Email address:}

chrysogonusnwaigwe@yahoo.com (C. C. Nwaigwe), iwuchuk@yahoo.com (H. C. Iwu)

\section{To cite this article:}

Nwaigwe, Chrysogonus Chinagorom; Iwu Hycinth Chukwudi. A Statistical Analysis of Value of Imports in Nigeria. American Journal of Theoretical and Applied Statistics. Vol. 3, No. 5, 2014, pp. 117-124. doi: 10.11648/j.ajtas.20140305.11

\begin{abstract}
The value of products imported into a country each year goes a long way to tell us how much the product is appreciated in the country. Some products form the major imports of some countries yearly. Previous studies have focused on the major determinants of imports in some countries, including Nigeria. In the present study, we used a regression approach to identify the major significant imports in Nigeria. This will help in the effective distribution of human resources and services and improve balance of payments. In using the above approach, the method of stepwise regression and transformation of the data via first-order differencing were employed to remove multicollinearity from the data. A predictive model was then specified for the prediction of future imports in the country. Our results show that the major significant imports in Nigeria during the period under study are miscellaneous manufactured goods, machinery and transport equipment, food and live animal, beverages and tobacco.
\end{abstract}

Keywords: Value of Imports, Statistical Analysis, Significant Factors, Regression, Predictive Model

\section{Introduction}

The value of products imported into a country plays a significant role in the international trade. Imports are key part of international trade and the import of capital goods in particular is vital to stimulating economic growth of a country. This is more often experienced in countries with limited productive capacity. In a country like, Nigeria where the Federal Government is trying to grow the economy by improving local capacity in the agricultural, manufacturing and other key sectors of the economy, analysis of value of imports into the country is highly essential. Knowing the value of the imports into the country will enable the Government to understand which areas of the economy need more attention to boost indigenous production. For example, according to the National Mirror of March 13, 2013, Nigeria witnessed a 43.1\% decline in the import trade value from 2011 to 2012 . It was also reported that at the end of 2012, the structure of import trade was dominated by the imports of mineral products, machinery and transport equipment, boilers and vegetable products. This decline, no doubt shows that the efforts by the Federal Government to grow the economy by improving local capacity in the agricultural, manufacturing and other key sectors of the economy are yielding desired results. Therefore, the present paper will no doubt through appropriate statistical methods compare the present result with the past and recommend to the Government which areas still require more efforts.

Effective balance of payments and better projection of foreign reserves are anchored in understanding the major significant imports in a country. Many authors have concentrated on the determinants of imports; for examples, Egwaikhide (2000) using a dynamic specification approach studied the determinants of imports in Nigeria. He observed that trade policies have been substantially influenced by the periodic balance of payments difficulties and the need to generate revenue. According to him, there have been frequent changes in import control measures in Nigeria, probably because of the conflict between raising revenue and maintaining a favourable balance of payments, on one hand and the need to protect import substituting industries on the other hand. Rogers (2000) concentrated on the determinants of Fiji's imports. According to his paper, to forecast the level of foreign reserves requires substantive analysis of the components of the balance of payments. He stated that, improvements in the balance of payments can eventuate through changes in the current account or the capital account. Balance of payments accounts are accounting record of all monetary transactions between a country and the rest of the world, Sloman (2004).

The value of imports also has great bearing in the value 
of a country's currency. For example, the Chinese government contributed to growth in U.S. imports by maintaining an undervalued currency between 1997 and 2007, Orang (2008). An undervalued Chinese currency would cause the dollar prices of U.S. imports from China to be lower than they would be in a competitive market. This development, however posed a challenge for competing U.S. manufacturers whose products must compete with the imports.

At this juncture, it has become obvious that the continuous analysis of the value of imports in a country is highly imperative. Though, the Nigerian Bureau of Statistics has the mandate to advice the Federal Government of Nigeria on the yearly significant imports in the country. The task should not be left alone for the Bureau as various and appropriate methods must be employed to identify these significant imports. The power of good predictive models cannot be underestimated in a nation that plans the future of her economy. In this study we have used both the method of transforming the data via first - order differencing and stepwise regression to ensure that the presence of multicollinearity in the data which could give false significant results does not jeopardise with the results of this study. A linear predictive model which could serve as a useful guide in predicting future imports into the country was provided and recommendations were given.

\subsection{Multicollinearity}

Multicollinear data are often undetected companion to econometric data and their presence, whether exposed or not renders ordinary least-squares estimates less precise and less useful than would otherwise be the case, Belsley (1976). Multicollinearity is problem that you can run into when you are fitting a regression model or other linear models. It refers to predictors that are correlated with other predictors in the model. Severe multicollinearity can increase the variance of the coefficient estimates and make the estimates very sensitive to minor changes in the model. The result is that the coefficient estimates are unstable and difficult to interpret. Multicollinearity causes the coefficients to change signs and make it more difficult to specify the correct model. According to Belsley et al (1980), multicollinearity also yields high $R^{2}$. Tull and Hawkins (1990) and Lehmann et al (1998) respectively suggest 0.35 and 0.7 as a threshold of bivariate correlations for the harmful effect of multicollinearity. Regarding other multicollinearity diagnostics, Belsley et al (1980) and Johnston (1984) suggested condition indices (CI) less than 20 are not problematic. Hair et al (1995) suggested variance inflation factors (VIF) less than 10 are indicative of inconsequential multicollinearity. Stepwise regression can be used to determine superfluous variables when the data are multicollinear. Multicollinearity may be reduced by applying first difference method, removal of some of the variables that are correlated and increase in the number of observations used for the model.

\section{Specification of the Model}

The model that we intend to fit into the data is the multiple linear regression model. The usual form of the model is

$$
Y=\beta_{0}+\beta_{1} X_{1}+\beta_{2} X_{2}+\ldots+X_{p} \beta_{p}
$$

where $Y$ is the dependent variable, $X_{1}, X_{2}, \ldots X_{p}$ are the independent variables, otherwise, called the predictors, $\beta_{0}, \beta_{1}, \ldots, \beta_{p}$ are the parameters of the model indicating the number of units increase in $Y$ caused by one unit increase in the independent variables and $p$ is the number of independent variables in the model. Equation 2.1 is called the intercept model with $\beta_{0}$ as the intercept. When the intercept is not significant, it is often better to remove it from the model and specify the model as,

$$
Y=\beta_{1} X_{1}+\beta_{2} X_{2}+\ldots+X_{p} \beta_{p}
$$

Although, there are other forms of regression model, such as log linear regression, non-linear regression among others but a simple linear regression or multiple linear regression as the case may be often forms the starting model for investigation of better models.

\section{Analysis of Data and Discussion of Results}

In this section, we present the results of data analysed in this study and discuss the results of the analysis. The data used for this study were extracted from the Central Bank of Nigeria (CBN) Bulletin (2008), pp. 210-211. The following notations were used to represent the variables in the data:

$\mathrm{X}_{1}=$ Value of Food and Live Animal, $\mathrm{X}_{2}=$ Value of Beverages and Tobacco, $\mathrm{X}_{3}=$ Value of crude minerals inedible, $\mathrm{X}_{4}=$ Value of Mineral Fuels, $\mathrm{X}_{5}=$ Value of Animal and Vegetable Oils and Fats, $\mathrm{X}_{6}=$ Value of Chemicals, $\mathrm{X}_{7}=$ Value of Manufactured Goods, $\mathrm{X}_{8}=$ Value of Machinery and Transport Equipment, $\mathrm{X}_{9}=$ Value of Miscellaneous Manufactured Goods, $\mathrm{X}_{10}=$ Value of Miscellaneous Transactions, $\mathrm{Y}=$ Total Value of imports.

In order to determine the significant major imports in Nigeria from 1960-2008, we first employed the Ordinary Least Square Regression (OLS) to estimate the parameters of the model and identify the significant major imports in the country for the period under study. The total import for each year was used as the dependent variable.

The Statistical Package for Social Sciences (SPSS) was used to facilitate the calculations. Table 1 shows the model summary of the OLS. The results in Table 1 and Table 2 give a general indication that the independent variables used in the data are significant major imports in the country for the period under study at 0.05 level of significance. This is because, the P-value (0.000) is less than 0.05 . However, Table 1 shows that the $\mathrm{R}^{2}$ is very high indicating 
that the presence of multicollinearity might have affected the significance of the regressors. Further, when a T-test was conducted, It was found that only food and live animal, beverages and tobacco, machinery and transport equipment and miscellaneous manufactured goods were significant. This was because only these variables had $\mathrm{P}<0.05$. The variance inflation factors were all very high except for the variables, chemicals (see Table 3). All these indicate the presence of multicollinearity in the data whose effect, we have earlier enumerated. Table 4 gives the bivariate correlations between each pair of the independent variables. The results in Table 4 show that some of the independent variables are highly related; for example, the value of food and live animal imported into the country have high positive relationship with the value of beverages and tobacco (correlation coefficient of 0.802). Some of the condition indices as could be seen in Table 6 are as high as 40. This further shows the presence of multicollinearity.

Following the presence of multicollinearity in the data, we transformed the data using the First Difference Method. The results of the Ordinary Least Square Regression after transformation show that multicollinearity was still highly present in the data (see tables 6-10). Therefore, we had to run a stepwise regression in order to remove the superfluous variables. Our results show that the most essential variables needed in the regression model are food and live animal, beverages and tobacco, machinery and transport equipment and miscellaneous manufactured goods (see Table 11). Following this result, we removed other independent variables and regressed these selected variables on the total value of imports for each year. The results show that the multicollinearity was highly reduced. This could be attested by the moderate values of VIF and CI (see Table 15 and Table 16). When a T-test was performed, all the independent variables included in the regression were significant. However, the results also show that the constant term was not significant (see Table 12). Therefore, we re-ran the regression without the constant term. All the independent variables included were still significant (see Table 13, Table 14 and Table 15). Therefore, the appropriate regression model for the total value of imports from 1960 to 2008 is

Total import for the year $=2.358$ food and live animal + 41.871 beverages and tobacco +2.453 machine and transport equipment- 3.745 miscellaneous manufactured goods

This show that 1 million Naira increase each in the values of food and live animal, beverages and tobacco, machinery and transport equipment would cause the total import to increase by $2.358,41.871,2.453$ and decrease by -3.745 million Naira respectively.

Comparing this result with the result of the present time shows that importation of machinery and transport equipment still contributes significantly to the value of imports in Nigeria.

\section{Conclusion}

In this study, we have used different methods such as $\mathrm{R}^{2}$, bivariate correlation, VIF and $\mathrm{CI}$ to identify multicollinearity in data on the values of imports in Nigeria from 1960-2008. The method of first-order differencing was used to transform the data in order to remove the multicollinearity. It was found out that multicollinearity was still high in the data after the first -order differencing. Some of the predictors were still not significant when the Ttest was performed. A stepwise regression was then performed to identify the superfluous variables and remove them from the regression. The stepwise regression identified machinery and transport equipment $\left(\mathrm{X}_{8}\right)$, food and live animals $\left(\mathrm{X}_{1}\right)$, beverages and tobacco $\left(\mathrm{X}_{2}\right)$ and miscellaneous manufactured goods $\left(\mathrm{X}_{9}\right)$ as the only significant variables most useful in the presence of the multicollinearity. The ordinary least square regression was then re-run with only these four predictors and both the Ftest and the T-values for all the predictors were significant with highly reduced VIF, CI and bivariate correlation coefficients but the constant term was not significant. The constant term was removed and the ordinary least-square regression was again re-run in order to specify the appropriate model. We observed that the appropriate model for predicting the value of imports in Nigeria is given by $\mathrm{Y}$ $=2.358 \mathrm{X}_{1}+41.871 \mathrm{X}_{2}+2.453 \mathrm{X}_{8}-3.745 \mathrm{X}_{9}$, where $\mathrm{Y}$ is the total import for the year. When these results were compared with the current report of the Nigerian Bureau of Statistics, it was found out that machinery and transport equipment still contributes significantly to the Value of Nigerian imports. We therefore recommend that if Nigeria wishes to further reduce her value of imports, more effort should be made to establish industries in the country for local production of machinery and transport equipment. We caution that while Nigeria currently encourages the production and patronage of indigenous products efforts should be made to strike a balance so that the value of her currency is not further devalued due to insufficiency of the indigenous products in the country.

Table 1. Model summary of the OLS without Transformation of data

\begin{tabular}{|c|c|c|c|c|c|c|c|c|c|}
\hline \multirow{2}{*}{ model } & \multirow{2}{*}{$\mathbf{R}$} & \multirow{2}{*}{ R Square } & \multirow{2}{*}{$\begin{array}{l}\text { Adjusted R } \\
\text { square }\end{array}$} & \multirow{2}{*}{$\begin{array}{l}\text { Std. Error of } \\
\text { the Estimate }\end{array}$} & \multicolumn{5}{|l|}{ Change Statistics } \\
\hline & & & & & R square change & F change & df1 & df2 & Sig. F change \\
\hline 1 & $1.000^{\mathrm{a}}$ & .999 & .999 & 25831.43992 & .999 & 6578.779 & .10 & 37 & .000 \\
\hline
\end{tabular}

a. Predictors: (constant), X10, X6,X9, X1, X3, X8, X5, X2, X7, X4 
Table 2. ANOVA table of the OLS without Transformation of Data

\begin{tabular}{|c|c|c|c|c|c|}
\hline Model & Sum of squares & df & Mean square & $\mathbf{F}$ & Sig. \\
\hline Regression & $4.390 \mathrm{E} 13$ & 10 & $4.390 \mathrm{E} 12$ & & \\
\hline Residual & $2.469 \mathrm{E} 10$ & 37 & $6.673 \mathrm{E} 8$ & 6578.779 & $.000^{\mathrm{a}}$ \\
\hline Total & $4.392 \mathrm{E} 13$ & 47 & & & \\
\hline
\end{tabular}

a. Predictors: (constant), X10, X6,X9, X1, X3, X8, X5, X2, X7, X4

b. Dependent Variable: Total

Table 3. Parameters and the VIF of the OLS without Transformation of Data

Coefficients $^{a}$

\begin{tabular}{|c|c|c|c|c|c|c|c|}
\hline \multirow{2}{*}{ Model } & \multicolumn{2}{|c|}{ Unstandardized Cofficients } & \multirow{2}{*}{$\begin{array}{l}\text { Standardized coefficients } \\
\text { Beta }\end{array}$} & \multirow{2}{*}{$\mathbf{t}$} & \multirow{2}{*}{ Sig. } & \multicolumn{2}{|c|}{ Collinearity Statistics } \\
\hline & B & Std. Error & & & & Tolerance & VIF \\
\hline 1 (Contant) & -293.046 & 4731.194 & & -.062 & .951 & & \\
\hline $\mathrm{X} 1$ & 2.329 & .770 & .178 & 3.024 & .005 & .004 & 228.975 \\
\hline $\mathrm{X} 2$ & 28.990 & 15.256 & .286 & 1.900 & 0.65 & .001 & 1493.486 \\
\hline $\mathrm{X} 3$ & 4.044 & 4.193 & .233 & .964 & .341 & .000 & 3838.254 \\
\hline $\mathrm{X} 4$ & -1.964 & 12.495 & -.035 & .157 & .876 & .000 & 3232.842 \\
\hline $\mathrm{X} 5$ & -2.812 & 5.443 & -.063 & -.517 & .608 & .001 & 967.907 \\
\hline X6 & .001 & .009 & .001 & .163 & .871 & .194 & 5.151 \\
\hline $\mathrm{X} 7$ & 0.27 & .436 & 009 & 0.062 & .951 & .001 & 1287.647 \\
\hline X8 & 1.821 & .344 & .412 & 5.300 & .000 & .003 & 398.190 \\
\hline X9 & -1.951 & 1.396 & 0.71 & -1.398 & .171 & .006 & 172.003 \\
\hline $\mathrm{X} 10$ & 13.607 & 10.329 & 0.57 & 1.317 & .196 & .008 & 123.906 \\
\hline
\end{tabular}

a. Dependent Variable: Total

Table 4. Correlation Coefficients of the OLS without Transformation of Data

Coefficient Correlations

\begin{tabular}{|c|c|c|c|c|c|c|c|c|c|c|}
\hline Model & X10 & X6 & X9 & $\mathbf{X 1}$ & $\mathbf{X 3}$ & X8 & X5 & $\mathrm{X} 2$ & $\mathbf{X} 7$ & $\mathrm{X} 4$ \\
\hline Correlations X10 & 1.000 & .159 & .462 & -.416 & .316 & -.100 & -.220 & -.305 & .157 & -.273 \\
\hline X6 & .159 & 1.000 & .183 & -.333 & .651 & -.098 & .471 & -.522 & .313 & -.787 \\
\hline X9 & .462 & .183 & 1.000 & -.853 & .458 & -.136 & .302 & -.808 & .254 & -.322 \\
\hline $\mathrm{X} 1$ & -.416 & -.333 & -.853 & 1.000 & -.392 & -.187 & -.422 & .822 & -.431 & .456 \\
\hline $\mathrm{X} 3$ & .316 & .651 & .458 & -.392 & 1.000 & -.255 & .439 & -.717 & -.042 & -.805 \\
\hline $\mathrm{X} 8$ & -.100 & -.098 & -.136 & -.187 & -.255 & 1.000 & .073 & .090 & -.324 & .132 \\
\hline $\mathrm{X} 5$ & -.220 & .471 & .302 & -.422 & .439 & .073 & 1.000 & -.698 & .358 & -.731 \\
\hline $\mathrm{X} 2$ & -.305 & -.522 & -.808 & .822 & -.717 & .090 & -.698 & 1.000 & -.391 & .739 \\
\hline$X 7$ & .157 & .313 & .254 & -.431 & -.042 & -.324 & .358 & -.391 & 1.000 & -.386 \\
\hline $\mathrm{X} 4$ & -.273 & -.787 & -.322 & .456 & -.805 & .132 & -.731 & .739 & -386 & 1.000 \\
\hline CovarianceX10 & 106.691 & .014 & 6.666 & 3.308 & 13.686 & -.355 & 12.389 & 48.125 & .709 & 35.180 \\
\hline X6 & .014 & $7.503 \mathrm{E}-5$ & .002 & -002 & .024 & .000 & .022 & -.069 & .001 & -.085 \\
\hline X9 & 6.666 & .002 & 1.948 & -917 & 2.681 & -.065 & 2.297 & 17.213 & .155 & 5.623 \\
\hline $\mathrm{X} 1$ & -.3 .308 & -.002 & -.917 & .593 & -1.265 & -.049 & -1.769 & 9.657 & -.145 & 4.393 \\
\hline X3 & 13.686 & .024 & 2.681 & 1.265 & 17.583 & -.368 & 10.024 & 45.884 & -.077 & 42.182 \\
\hline $\mathrm{X} 8$ & -.355 & .000 & -.065 & -.049 & -.368 & .118 & .137 & .473 & -.049 & .565 \\
\hline $\mathrm{X} 5$ & .12 .389 & .022 & 2.297 & 1.769 & 10.024 & .137 & 29.621 & 57.954 & .850 & 49.691 \\
\hline $\mathrm{X} 2$ & -48.125 & -.069 & -17.213 & 9.657 & -45.884 & .473 & 57.654 & 232.752 & 2.606 & 140.85 \\
\hline$X 7$ & .709 & .001 & .155 & -.145 & -.077 & -.049 & .850 & -2.606 & .190 & -2.106 \\
\hline $\mathrm{X} 4$ & -35.180 & -.085 & -5.623 & 4.393 & -42.182 & .565 & 49.691 & 140.856 & 2.106 & 156.123 \\
\hline
\end{tabular}

a. Dependent Variable: Total 
Table 5. Condition Index of the OLS without Transformation of Data

Collinearity Diagnostics

\begin{tabular}{|c|c|c|c|c|c|c|c|c|c|c|c|c|c|}
\hline \multirow{2}{*}{$\begin{array}{l}\text { Model } \\
\text { dimension }\end{array}$} & \multirow{2}{*}{ Eigen value } & \multirow{2}{*}{$\begin{array}{l}\text { Condition } \\
\text { index }\end{array}$} & \multicolumn{11}{|c|}{ Variance Proportions } \\
\hline & & & (constant) & $\mathrm{X} 1$ & $\mathrm{X} 2$ & $\mathbf{X 3}$ & $\mathrm{X4}$ & X5 & X6 & $\mathbf{X} 7$ & X8 & X9 & $\mathrm{X} 10$ \\
\hline 1 & 9.316 & 1.000 & .00 & .00 & .00 & .00 & .00 & .00 & .00 & .00 & .00 & .00 & .00 \\
\hline 2 & .837 & 3.337 & .62 & .00 & .00 & .00 & .00 & .00 & .02 & .00 & .00 & .00 & .00 \\
\hline 3 & .624 & 3.833 & .11 & .00 & .00 & .00 & .00 & .00 & .23 & .00 & .00 & .00 & .00 \\
\hline 4 & .173 & 7.335 & .10 & .00 & .00 & .00 & .00 & .00 & .05 & .00 & .00 & .01 & .01 \\
\hline 5 & 0.32 & 17.028 & .06 & .04 & .00 & .00 & .00 & .00 & .00 & .00 & .00 & .03 & .01 \\
\hline 6 & .012 & 27.401 & .00 & .00 & .00 & .00 & .00 & .00 & .04 & .01 & .02 & .04 & .26 \\
\hline 7 & .003 & 60.455 & .06 & .09 & .00 & .00 & 01 & .10 & .03 & .00 & .28 & .00 & .39 \\
\hline 8 & .001 & 90.716 & .02 & .43 & .20 & .00 & .06 & .00 & .07 & .00 & .05 & .59 & .04 \\
\hline 9 & .001 & 91.831 & .02 & .00 & .00 & .01 & .01 & .27 & .00 & .10 & .61 & .05 & .20 \\
\hline 10 & .000 & 146.504 & .02 & .11 & .04 & .14 & .02 & .15 & .01 & .80 & .00 & .01 & .00 \\
\hline 11 & .000 & 299.385 & .00 & .32 & .75 & .84 & .91 & .48 & .54 & .08 & .04 & .27 & .09 \\
\hline
\end{tabular}

a. Dependent Variable

Table 6. Model Summary of the Transformed Data Model Summary

\begin{tabular}{|c|c|c|c|c|c|c|c|c|c|}
\hline \multirow{2}{*}{ Model } & \multirow{2}{*}{$\mathbf{R}$} & \multirow{2}{*}{ R Square } & \multirow{2}{*}{$\begin{array}{l}\text { Adjusted R } \\
\text { Square }\end{array}$} & \multirow{2}{*}{$\begin{array}{l}\text { Std. Error of the } \\
\text { Estimate }\end{array}$} & \multicolumn{5}{|l|}{ Change Statistics } \\
\hline & & & & & R Square Change & F Change & Df1 & Df2 & Sig.F Change \\
\hline 1 & .993 & .986 & .983 & 41450.61666 & .986 & 269.442 & 10 & 37 & .000 \\
\hline
\end{tabular}

a. Predictors: (constant), DX10, DX6, DX9, DX4, DX1, DX2, DX7, DX8, DX5, DX3

Table 7. ANOVA table for the Transformed Data

\begin{tabular}{lllll}
\hline Model & Sum of Squares & df & Mean Square & F \\
\hline Regression & $4.629 \mathrm{E} 12$ & 10 & $4.629 \mathrm{E} 11$ & \\
Residual & $6.357 \mathrm{E} 10$ & 37 & $1.718 \mathrm{E} 9$ & 269.442 \\
Total & $4.693 \mathrm{E} 12$ & 47 & & $.000^{\mathrm{a}}$ \\
\hline
\end{tabular}

a. Predictors: (constant), DX10, DX6,DX9,DX4,DX1,DX2,DX7,DX8,DX5,DX3

b. Dependent Variable: DTotal

Table 8. Parameters and VIF of the Transformed Data

Coefficients $^{a}$

\begin{tabular}{|c|c|c|c|c|c|c|c|}
\hline \multirow{2}{*}{ Model } & \multicolumn{2}{|c|}{ Unstandardized coefficients } & \multirow{2}{*}{ Beta } & \multirow{2}{*}{$\mathbf{T}$} & \multirow{2}{*}{ Sig. } & \multicolumn{2}{|c|}{ Collinearity Statistics } \\
\hline & B & Std. Error & & & & Tolerance & VIF \\
\hline 1 (constant) & -3419.375 & 6838.068 & & -.500 & .620 & & \\
\hline DX1 & 2.936 & 1.004 & .194 & 2.925 & .006 & .083 & 12.004 \\
\hline DX2 & 42.380 & 16.500 & .400 & 2.568 & .014 & .015 & 66.366 \\
\hline DX3 & -2.582 & 5.650 & -.137 & -.457 & .650 & .004 & 244.234 \\
\hline DX4 & -2.417 & 8.863 & .039 & .273 & .787 & .018 & 56.851 \\
\hline DX5 & .276 & 5.868 & .008 & .047 & .963 & .013 & 76.519 \\
\hline DX6 & .004 & .007 & .017 & .596 & .555 & .452 & 2.211 \\
\hline DX7 & .796 & .451 & .266 & 1.766 & .086 & .016 & 62.002 \\
\hline DX8 & 1.481 & .598 & .329 & 2.478 & .018 & .021 & 48.183 \\
\hline DX9 & -2.336 & 1.755 & -.092 & -1.331 & .191 & .077 & 13.032 \\
\hline DX10 & 1.436 & 15.919 & .010 & .090 & .929 & .032 & 31.712 \\
\hline
\end{tabular}

a. Dependent Variable: DTotal 
Table 9. Correlation Coefficients of the Transformed Data

Coefficient Correlations

\begin{tabular}{|c|c|c|c|c|c|c|c|c|c|c|}
\hline Model & DX10 & DX6 & DX9 & DX4 & DX1 & DX2 & DX7 & DX8 & DX5 & DX3 \\
\hline CorrelationDX10 & 1.000 & -.033 & .385 & .369 & -.138 & .077 & -.052 & .479 & -.849 & -.241 \\
\hline DX6 & -.033 & 1.000 & .088 & -.400 & .180 & -.073 & -.156 & -.240 & .003 & .334 \\
\hline DX9 & .385 & .088 & 1.000 & .120 & -.577 & -.555 & -.214 & .060 & -.088 & .219 \\
\hline DX4 & .369 & -.400 & .120 & 1.000 & .098 & .575 & .423 & .292 & -.543 & -.895 \\
\hline DX1 & -.138 & .180 & -.577 & .098 & 1.000 & .653 & .176 & -.475 & -.176 & -227 \\
\hline DX2 & .077 & -.073 & -.555 & .575 & .653 & 1.000 & .358 & -.037 & -.475 & -.724 \\
\hline DX7 & -.052 & -.156 & -.214 & .423 & .176 & .358 & 1.000 & -.173 & -.303 & -.614 \\
\hline DX8 & .479 & -.240 & .060 & .292 & -.475 & -.037 & -.173 & 1.000 & -.319 & -.338 \\
\hline DX5 & -.849 & .003 & -.088 & -.543 & -.176 & -.475 & -.303 & -.319 & 1.000 & .521 \\
\hline DX3 & -.241 & .334 & .219 & -.895 & -.227 & -.724 & -.614 & -.338 & .521 & 1.000 \\
\hline CovarianceDX10 & 253.423 & -.004 & 10.745 & 51.991 & -2.202 & 20.112 & -374 & 4.562 & -79.334 & -21.670 \\
\hline DX6 & -.004 & $5.015 \mathrm{E}-5$ & .001 & -.025 & .001 & -.009 & .000 & -.001 & .000 & .013 \\
\hline DX9 & 10.745 & .001 & 3.079 & 1.866 & -1.017 & -16.077 & -.169 & .063 & -.907 & 2.167 \\
\hline DX4 & 51.991 & -.025 & 1.866 & 78.546 & .874 & 84.053 & 1.691 & 1.548 & -28.244 & -44.825 \\
\hline DX1 & -.2 .202 & .001 & -1.017 & .874 & 1.008 & 10.812 & .080 & -.285 & -1.034 & -1.288 \\
\hline DX2 & 20.112 & -.009 & -16.077 & 84.053 & 10.812 & 272.265 & 2.663 & -.366 & -45.952 & -67.471 \\
\hline DX7 & -.374 & .000 & -.169 & 1.691 & .080 & 2.663 & .203 & -.047 & -.802 & -1.563 \\
\hline DX8 & 4.562 & -.001 & .063 & 1.548 & -.285 & -.366 & -.047 & .357 & -1.118 & -1.143 \\
\hline DX5 & -79.334 & .000 & -.907 & -28.244 & -1.034 & -45.952 & -.802 & -1.118 & 34.439 & 17.271 \\
\hline DX3 & -21.670 & .013 & 2.167 & -44.825 & -1.288 & -67.471 & -1.563 & -1.143 & 17.271 & 31.919 \\
\hline
\end{tabular}

a. Dependent Variable : DTotal

Table 10. Condition Index of the Transformed Data

\begin{tabular}{|c|c|c|c|c|c|c|c|c|c|c|c|c|c|}
\hline \multirow{2}{*}{ Model Dimension } & \multirow{2}{*}{$\begin{array}{l}\text { Eigen } \\
\text { value }\end{array}$} & \multirow{2}{*}{$\begin{array}{l}\text { Condition } \\
\text { index }\end{array}$} & \multicolumn{11}{|c|}{ Variance Proportions } \\
\hline & & & (constant) & DX1 & DX2 & DX3 & DX4 & DX5 & DX6 & DX7 & DX8 & DX9 & DX10 \\
\hline 1. & 7.415 & 1.000 & .00 & .00 & .00 & .00 & .00 & .00 & .00 & .00 & .00 & .00 & .00 \\
\hline 2. & 1.618 & 2.141 & .00 & .00 & .00 & .00 & .00 & .00 & .14 & .00 & .00 & .01 & .00 \\
\hline 3. & .840 & 2.970 & .87 & .00 & .00 & .00 & .00 & .00 & .00 & .00 & .00 & .00 & .00 \\
\hline 4. & .480 & 3.932 & .02 & .01 & .00 & .00 & .00 & .00 & .04 & .00 & .00 & .00 & .03 \\
\hline 5. & .351 & 4.596 & .00 & .00 & .00 & .00 & .01 & .00 & .58 & .00 & .00 & .06 & .00 \\
\hline 6. & .211 & 5.927 & .00 & .21 & .01 & .00 & .00 & .00 & .00 & .00 & .00 & .02 & .01 \\
\hline 7. & .038 & 14.000 & .03 & .00 & .00 & .00 & .15 & .00 & .01 & .04 & .13 & .41 & .00 \\
\hline 8. & .020 & 19.455 & .01 & .14 & .20 & .00 & .00 & .02 & .00 & .38 & .03 & .19 & .02 \\
\hline 9. & .016 & 21.773 & .03 & .35 & .13 & .02 & .02 & .26 & .13 & .01 & .27 & .02 & .10 \\
\hline 10. & .010 & 27.766 & .00 & .21 & .07 & .01 & .01 & .30 & .00 & .18 & .47 & .25 & .72 \\
\hline 11. & .002 & 57.692 & .03 & .07 & .58 & .97 & .80 & .42 & .09 & .38 & .10 & .04 & .12 \\
\hline
\end{tabular}

a. Dependent Variable: DTotal 
Table 11. Results of the Stepwise Regression

Coefficient

\begin{tabular}{|c|c|c|c|c|c|c|c|}
\hline \multirow{2}{*}{ Model } & \multicolumn{2}{|c|}{ Unstandardized coefficients } & \multirow{3}{*}{$\begin{array}{l}\text { Standard Coefficients } \\
\text { Beta } \\
.998\end{array}$} & \multirow{3}{*}{$\begin{array}{l}\mathbf{t} \\
1.698\end{array}$} & \multirow{3}{*}{$\begin{array}{l}\text { Sig } \\
.096\end{array}$} & \multicolumn{2}{|c|}{ Collinearity Statistics } \\
\hline & \multirow{2}{*}{$\begin{array}{l}\text { B } \\
14722.433\end{array}$} & \multirow{2}{*}{$\begin{array}{l}\text { Std. Error } \\
8669.475\end{array}$} & & & & Tolerance & VIF \\
\hline 1. (constant) & & & & & & 1000 & \\
\hline $\mathrm{X} 7$ & 3.115 & .025 & & 122.466 & .000 & 1.000 & \\
\hline 2. (constant) & -4033.056 & 6148.525 & & -.856 & .515 & & \\
\hline $\mathrm{X} 7$ & 1.716 & .178 & .550 & 9.652 & .000 & .009 & 114.138 \\
\hline $\mathrm{X} 8$ & 1.990 & .252 & .450 & 7.903 & .000 & .009 & 114.138 \\
\hline 3. (constant) & -3865.218 & 5412.439 & & -.714 & .479 & & \\
\hline $\mathrm{X} 7$ & .741 & .303 & .238 & 2.445 & .019 & .002 & 428.623 \\
\hline $\mathrm{X} 8$ & 2.735 & .298 & .619 & 9.192 & .000 & .005 & 205.657 \\
\hline $\mathrm{X} 5$ & 6.577 & 1.753 & .147 & 3.752 & .001 & .014 & 69.192 \\
\hline 4. (constant) & -4074.023 & 5171.433 & & -.788 & .435 & & \\
\hline $\mathrm{X} 7$ & .836 & .293 & .268 & 2.856 & .007 & .002 & 437.371 \\
\hline $\mathrm{X} 8$ & 2.205 & .367 & .499 & 6.008 & .000 & .003 & 342.821 \\
\hline $\mathrm{X} 5$ & 7.997 & 1.786 & .178 & 4.476 & .000 & .013 & 76.740 \\
\hline $\mathrm{X} 1$ & .793 & .347 & .061 & 2.283 & .027 & .028 & 35.136 \\
\hline 5. (constant) & -1617.574 & 4890.972 & & -.331 & .742 & & \\
\hline $\mathrm{X} 7$ & .713 & .276 & .229 & 2.585 & .013 & .002 & 448.947 \\
\hline $\mathrm{X} 8$ & 1.961 & .353 & .444 & 5.562 & .000 & .003 & 365.605 \\
\hline $\mathrm{X} 5$ & 6.015 & 1.809 & .134 & 3.325 & .002 & .011 & 93.292 \\
\hline $\mathrm{X} 1$ & 1.113 & .343 & .085 & 3.246 & .002 & .025 & 39.631 \\
\hline $\mathrm{X} 2$ & 11.707 & 4.219 & .116 & 2.775 & .008 & .010 & 99.660 \\
\hline 6. (constant) & -427.860 & 4546.131 & & -.094 & .925 & & \\
\hline $\mathrm{X} 7$ & .289 & .296 & .093 & .977 & .335 & .002 & 603.209 \\
\hline $\mathrm{X} 8$ & 1.959 & .326 & .443 & 6.006 & .000 & .003 & 365.606 \\
\hline $\mathrm{X} 5$ & 1.007 & 2.434 & .022 & .414 & .681 & .005 & 197.236 \\
\hline $\mathrm{X} 1$ & 2.682 & .638 & .205 & 4.203 & .000 & .006 & 160.195 \\
\hline $\mathrm{X} 2$ & 36.289 & 9.512 & .358 & 3.815 & .000 & .002 & 591.507 \\
\hline X9 & -3.185 & 1.1214 & -.117 & -2.834 & .007 & .009 & 113.638 \\
\hline 7. (constant) & -211.565 & 4471.186 & & -.047 & .962 & & \\
\hline $\mathrm{X} 7$ & .288 & .293 & .092 & .985 & .330 & .002 & 603.201 \\
\hline $\mathrm{X} 8$ & 1.928 & .314 & .436 & 6.134 & .000 & .003 & 346.198 \\
\hline $\mathrm{X} 1$ & 2.834 & .518 & .217 & 5.468 & .000 & .009 & 107.737 \\
\hline $\mathrm{X} 2$ & 39.333 & 5.969 & .388 & 6.589 & .000 & .004 & 237.634 \\
\hline $\mathrm{X} 9$ & -3.522 & .765 & -.129 & -4.603 & .000 & .019 & 53.750 \\
\hline 8. (constant) & -514.852 & 4459.003 & & -.115 & .909 & & \\
\hline $\mathrm{X} 8$ & 2.133 & .236 & .483 & 9.037 & .000 & .005 & 195.256 \\
\hline $\mathrm{X} 1$ & 3.085 & .451 & .236 & 6.839 & .000 & .012 & 81.659 \\
\hline $\mathrm{X} 2$ & 44.112 & 3.476 & .436 & 12.692 & .000 & .012 & 80.609 \\
\hline X9 & -4.074 & .522 & -.149 & -7.811 & .000 & .040 & 24.986 \\
\hline
\end{tabular}

a. Dependent Variable: Total

Table 12. Parameters of the OLS with the identified significant Independent Variables and non-signature Intercept Term

Coefficients

\begin{tabular}{|c|c|c|c|c|c|c|c|}
\hline \multirow{2}{*}{ Model } & \multicolumn{2}{|c|}{ Unstandardized Coefficients } & \multirow{2}{*}{$\begin{array}{l}\text { Standardized coefficient } \\
\text { Beta }\end{array}$} & \multirow{2}{*}{$\mathbf{T}$} & \multirow{2}{*}{ Sig. } & \multicolumn{2}{|c|}{ Collinearity Statistics } \\
\hline & B & Std. Error & & & & Tolerance & VIF \\
\hline (constant) & -2334.732 & 5237.269 & & -.446 & .658 & & \\
\hline $\mathrm{X} 1$ & 2.346 & .491 & .163 & 4.772 & .000 & .010 & 95.578 \\
\hline $\mathrm{X} 2$ & 41.378 & 4.031 & .413 & 10.266 & .000 & .008 & 131.975 \\
\hline $\mathrm{X} 8$ & 2.478 & .262 & .553 & 9.471 & .000 & .004 & 278.442 \\
\hline X9 & -3.724 & .608 & -.126 & -6.127 & .000 & .029 & 34.587 \\
\hline
\end{tabular}

a. Dependent Variable: Total 
Table 13. Model Summary of the Final OLS Regression Containing the Major Significant Variable

Model Summary

\begin{tabular}{|c|c|c|c|c|c|c|c|c|c|}
\hline \multirow[b]{2}{*}{ Model } & \multirow[b]{2}{*}{$\mathbf{R}$} & \multirow[b]{2}{*}{ R Square ${ }^{b}$} & \multirow{2}{*}{$\begin{array}{l}\text { Adjusted R } \\
\text { Square }\end{array}$} & \multirow{2}{*}{$\begin{array}{l}\text { Std. Error of } \\
\text { the Estimate }\end{array}$} & \multicolumn{5}{|c|}{ Change Statistics } \\
\hline & & & & & $\begin{array}{l}\text { R Square } \\
\text { Change }\end{array}$ & F Change & df1 & df2 & Sig. F. Change \\
\hline 1 & $1.000^{\mathrm{a}}$ & 1.000 & 1.000 & 29620.13828 & 1.000 & 25625.768 & 4 & 45 & .000 \\
\hline
\end{tabular}

a. Predictors: X9, X2, X1, X8

b. For regression through the origin (the no-intercept model), R square measures the proportion of the variability in the dependent variable about the origin explained by regression. This cannot be compared to R square for models which include an intercept.

Table 14. ANOVA Tables of the final OLS Regression containing the major Significant variable

$A N O V A^{c, d}$

\begin{tabular}{lllll}
\hline Model & Sum of squares & Df & Mean square & F \\
\hline Regression & $8.993 \mathrm{E} 13$ & 4 & $2.248 \mathrm{E} 13$ & \\
Residual & $3.948 \mathrm{E} 10$ & 45 & $8.774 \mathrm{E} 8$ & 25625.768 \\
Total & $8.997 \mathrm{E} 13$ & 49 & & $.000^{\mathrm{a}}$ \\
\hline
\end{tabular}

a. Predictors: $\mathrm{X} 9, \mathrm{X} 2, \mathrm{X} 1, \mathrm{X} 8$

b. This total sum of squares is not corrected for the constant because the constant is zero for regression through the origin.

c. Dependent Variable: Total

d. Linear Regression through the Origin

Table 15. Parameters and VIF of the OLS Regression Model with the major significant variables

Coefficient $t^{a, b}$

\begin{tabular}{|c|c|c|c|c|c|c|c|}
\hline \multirow{2}{*}{ Model } & \multicolumn{2}{|c|}{ Unstandardized Coefficeints } & \multirow{2}{*}{$\begin{array}{l}\text { Standardized Coefficient } \\
\text { Beta }\end{array}$} & \multirow{2}{*}{$\mathbf{t}$} & \multirow{2}{*}{ Sig. } & \multicolumn{2}{|c|}{ Collinearity Statistics } \\
\hline & B & Std. Error & & & & Tolerance & VIF \\
\hline $\mathrm{X} 1$ & 2.358 & .486 & .170 & 4.850 & .000 & .008 & 126.722 \\
\hline $\mathrm{X} 2$ & 41.871 & 3.842 & .409 & 10.898 & .000 & .007 & 144.695 \\
\hline $\mathrm{X} 8$ & 2.453 & .253 & .553 & 9.691 & .000 & .003 & 333.671 \\
\hline X9 & -3.745 & .600 & -.129 & -6.238 & .000 & .023 & 44.179 \\
\hline
\end{tabular}

a. Dependent Variable: Total

b. Linear Regression through the Origin

Table 16. Condition Index of the final OLS regression containing the major significant Variables

Collinearity Diagnostics ${ }^{a, b}$

\begin{tabular}{|c|c|c|c|c|c|c|}
\hline \multirow{2}{*}{ Model Dimension } & \multirow{2}{*}{ Eigen value } & \multirow{2}{*}{ Condition Index } & \multicolumn{4}{|c|}{ Variable Proportions } \\
\hline & & & $\mathrm{X} 1$ & $\mathrm{X} 2$ & X8 & $\mathbf{X 9}$ \\
\hline 1 & 3.911 & 1.000 & .00 & .00 & .00 & .00 \\
\hline 2 & .068 & 7.579 & .03 & .05 & .00 & .06 \\
\hline 3 & .019 & 14.185 & .13 & .01 & .02 & .62 \\
\hline 4 & .002 & 47.744 & .84 & .94 & .98 & .31 \\
\hline
\end{tabular}

a. Dependent Variable: Total

b. Linear Regression through the Origin

\section{References}

[1] Akinmutimi T. (2013). Nigeria's Import Bill dropped by N4.26 trn in 2012; National Mirror, March 13.

[2] Belsley (1976).Multicollinearity: Diagnosing its Presence and Assessing the potential damage it causes Least-Squares Estimation; NBER Working Paper Series.

[3] Belsley D. A., Kuh E. and Welsch R. E. (1980).Regression Diagnostics- Identifying Influential Data and Sources of Collinearity, John Wiley and Sons, New York.

[4] Egwaikhide F. O. (2000). Determinants of Imports in Nigeria: A Dynamic Specification; Publication and Dissemination, African Economic Research Consortium.
[5] Hair J. F., Anderson R. E., Tatham R. L. and Black W. C. (1995). Data Analysis, $3^{\text {rd }}$ ed, Macmillan Publishing Company, New York.

[6] Johnston J. (1984).Econometric Methods, $3^{\text {rd }}$ edn, McGrawHaill Publishing Company, New York.

[7] Lehmann D.R., Gupta S. and Steckel J. (1998).Marketing Research; Addison-Wesley Educational Publishers, Inc., Reading, Massachussetts.

[8] Rogers A. (2000).An Analysis of the Determinants of Fiji's Imports; Working Paper, Economics Department Reserve Bank of Fiji, Suva.

[9] Tull D. S. and Hawkins D. I. (1990).Marketing Research, $5^{\text {th }}$ edn, Macmillan Publishing Company, New York.

[10] Sloman J. (2004). Economics; Penguin. 